\title{
Assessment of Vulnerability of Escape Building against Earthquake and Tsunami at Padang City
}

\author{
Billy Richard \\ Agency of Public Works and Spatial Arrangement, West Pasaman District, INDONESIA \\ bilbukhary@gmail.com
}

\begin{abstract}
Earthquake occurred on September $30^{\text {th }}, 2009$ was the worst in the history of earthquake in West Sumatera. Damages of buildings were the main causes of human casualties at that time. The Regional Disaster Management Agency (Badan Penanggulangan Bencana Daerah, BPBD) of West Sumatera has conducted tsunami and earthquake mitigation, one of them is to prepare the Temporary Evacuation Site (TES) as a vertical-evacuation building allowing people to escape from tsunami attack in Padang City. This research was intended for evaluating and mapping the vulnerability potentials of all escape buildings to the earthquake and tsunami hazard. The investigation used Rapid Visual Screening method based on FEMA P-154 (Federal Emergency Management Agency) for assessing vulnerability of the building towards tsunami. According to the category of the obtained vulnerability potential, there were $50 \%, 33 \%, 10 \%$, and $7 \%$ of escape buildings identified safe, non-structurally vulnerable, structurally vulnerable from earthquake, and vulnerable to tsunami, respectively.
\end{abstract}

Keywords: mitigation, escape building, vulnerability assessment, earthquake, tsunami

\section{INTRODUCTION}

Some parts of the West Sumatera Province are coastal areas with characteristics of high seismicity, and vulnerable to high-magnitude earthquake threat. The movement of Eurasian and Indo-Australia tectonic plates, and also Mentawai fault allow shallow earthquakes to occur in the ocean, which could trigger tsunami into the mainland. As the capital of West Sumatera Province, Padang City has the highest potential risk in the world in the event of tsunami, with total of 508,804 out of 889,646 people being exposed. (BPBD Padang, 2016).

Aceh Tsunami event on December $26^{\text {th }}, 2004$ and in Nias on March $28^{\text {th }}, 2005$ caused a lot of casualties and severe damage to facilities and infrastructures. These events affected the lives of most West Sumatera community, particularly those who lives and works along the coast. The communities seem like have lost its ability to adapt to earthquake event. The Regional Disaster Management Agency (Badan Penanggulangan Bencana Daerah, BPBD) as the coordinator of disaster management has prepared engineered building that is functioned to be verticalevacuation building or escape building. Most of the escape buildings are multi-functioned, not only functioned as temporary evacuation site, so that building design does not fully focus on the escape function. Architecture, aesthetic, and location aspects sometimes make the escape buildings being less resistance to the damage caused by tsunami hazard.

The escape building is expected to have an immediate occupancy performance when the earthquake occurs, for instance no structural damage occurs, nonstructural components are still in place, and the building is still well functioned without any reparation. An effective and efficient mitigation could be conducted through evaluation on building vulnerability potential. By the means of visual observation/Rapid Visual Screening (RVS) according to the FEMA (Federal Emergency Management Agency) P-154 on level 1 and level 2 checking, as well as FEMA P-646 criteria, initial assessment of existing condition of escape building could be quickly provided.

\section{VULNERABILITY OF BUILDING AGAINST DISASTER}

In general, earthquake is defined as a detected vibration from the surface of the earth that is resulted from seismic waves which are caused by sudden energy release from within the earth (Hunt, 2007). Zulfiar, et.al (2014) revealed that vulnerability of building is technically caused by topography or location, suitable material utilization, building shape, quality and building structure system, maintenance, people awareness on earthquake disaster, capacity of the expertise in planning earthquake mitigation, and supervising on building construction. 
Secondary impact of the earthquake is tsunami. It can occur in the event of disturbance or interaction between sea-bottom motions that then caused displacement of large quantities of water, such as volcano eruption dislocation, landslide, and meteor or other objects that fall into earth water (Triatmadja, 2010). However, the majority cause of tsunami events is result of oceanbottom earthquake.

\section{DISASTER MANAGEMENT}

Earthquake disaster management is series of activities on each disaster phase linking each other like a cycle, as shown in Figure 1. A good disaster risk management in each disaster phase can effectively reduce the overall risk of disaster. Mitigation is a series of efforts to reduce the disaster risk, both by physical mitigation or non-physical mitigation, such as increasing awareness and capacity building in responding a disaster. Preparedness is a series of activities conducted to anticipate disaster by planning effective and efficient disaster mitigation and coordination among institutions and community in facing disaster (BNPB, 2007).

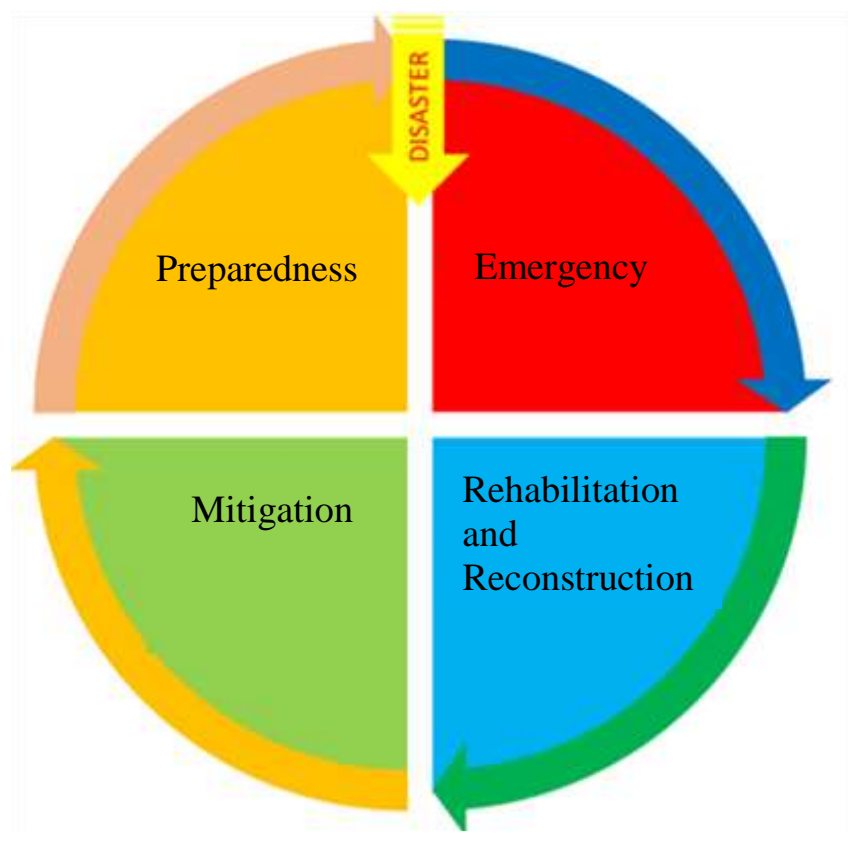

Figure 1. Disaster management cycle.

\subsection{Rapid Visual Screening (RVS) (FEMA P-154, 2015)}

Building vulnerability evaluation by RVS method was conducted through observation and score-filling on questionnaire forms. Basic score for various building types is already provided in the forms. Screener modifies basic score by identifying score modifier, which corresponds to the conformity between attribute and the observed building. It is added (or subtracted) with the basic score, up to the final score.
Final score of 2 is defined as a cut-off based on seismic design criteria from the National Bureau of Standards (NBS, 1980). If the building receives a score which is below 2, as according to RVS procedure, it must be evaluated by professional experts who have experienced with seismic evaluation and earthquake resistant building design.

Building vulnerability is affected by several attributes, such as:

a) Seismicity, which comes from the value of spectral acceleration (SA) response on the site location; this value then would determine the classification of high or low seismicity

b) Year of the building being constructed, in order to find whether the building is constructed before the Building Regulation (code), or after the renewal year of the Building Regulation (benchmark);

c) Soil Type, which also known as soil class, that has huge impact on the amplification;

d) Geological hazard, such as liquefaction, landslide potential, and crack/fracture on the soil surface;

e) Building proximity, as for interaction between adjacent buildings which can cause several types of damages during the earthquake;

f) Irregularity (plan irregularity and vertical irregularity), which is caused by architectural, functional, and economical reason, can harm and affect the seismic performance of the building;

g) Exterior and interior non-structural hazard, which can endanger human lives.

\subsection{FEMA P-646 (FEMA P-646, 2012)}

Guidelines for vertical evacuation building design in FEMA P-646 were used as the visual rating. Evaluation method was visual observation on escape building by considering parameter, standards, and principals on site determination, accessibility, distance, size, and elevation. Potential hazards around the location must be considered in determining building construction site. If it is possible, the building must be located far from the hazard that can cause additional damage to the structure and endanger the safety of the building users.

Evacuation process in terms of tsunami rescue is categorized as short-term evacuation. Duration of evacuation in the building was estimated to be at least 8 to 12 hours. The area requirements were also used for short-term evacuation building evacuation plan on another natural hazard; the minimal area requirement per evacuee was 10 square feet $( \pm 1$ square meter).

The magnitude of tsunami effect was determined by assuming a maximum tsunami rise would result on 
elevation that $30 \%$ higher than predicted by numerical simulation of tsunami inundation modeling. Recommendation for minimal building elevation is elevation of predicted tsunami inundation plus $30 \%$, plus 3 meters.

\section{RESEARCH METHOD}

This research was conducted in Padang City located on the west coast of Sumatra Island, between $0^{\circ} 44^{\prime} 00^{\prime \prime}$ and $1^{\circ} 08^{\prime} 35^{\prime}$ 'S, and between $100^{\circ} 05^{\prime} 05^{\prime \prime}$ and $100^{\circ}$ 34' 09'E. According to the Government Regulation No. 17 Year 1980, the area of Padang City is 694.96 $\mathrm{km}^{2}$. Most of the total Padang City area or $51.01 \%$ of the total area is a government-protected forest, while the area of buildings and house yard is of $51.08 \mathrm{~km}^{2}$ area or $7.35 \%$.

This research went through several stages, which consisted of several implemented stages. They were pre-field data collecting, field data collection, evaluation on potential vulnerability to earthquake, and evaluation on potential vulnerability to tsunami.

\section{RESULT AND DISCUSSION}

\subsection{Evaluation on Potential Vulnerability of Escape Building to Earthquake with FEMA P-154}

The value of short-period response spectrum $(0.2$ seconds)/SS value and value of long-period response spectrum (1 second)/S1 value at 25 escape building locations, including the 'High Seismicity' zone; $1 \mathrm{~g} \leq$ $\mathrm{SS}<1.5 \mathrm{~g}$ and $0.4 \mathrm{~g} \leq \mathrm{S} 1<0.6 \mathrm{~g}$.

Two soil types were found in the location of the escape building which belongs to medium soil/D $(15<\mathrm{N}<50)$ and soft soil/E $(\mathrm{N}<15)$. Potential hazard of liquefaction on escape building location was categorized into low and medium threat category (Hatta, 2014).

After pre-field analysis was obtained, observation conducted by applying Rapid Visual Screening (RVS) method was thoroughly performed on the building exterior and interior parts. Every potential cause of vulnerability by earthquake, such as structural and nonstructural hazards and observed geological hazard, were then recorded to be transferred into Level 1 and Level 2 RVS FEMA P-154 format.

\subsection{Result of Assessment on Potential Vulnerability of Escape Building to Earthquake with FEMA P- 154}

Based on the result of conducted identification and field data review on 25 locations, escape building was divided into 30 buildings because several locations have more than one building and structure. The structural types were divided into two structural systems, i.e. C1 (concrete moment-resisting frame) and S2 (steel bracing frame). The escape buildings were categorized into two types, i.e. existing building and new building functioned as a temporary escape building.

Evaluation of level 1 more focused on the initial identification and information about the escape building related to the building potential vulnerability to earthquake which was classified according to basic score, construction year of the building in relation with the application of building structure regulation (precode or post-benchmark), total level of the building, geological hazards that exist on the location and potentially hazardous (liquefaction, landslide, soil cracking, the potential for other hazards, such as the possibility of collapse from other buildings, impact of the building structure with other adjacent building structure, soil type which would affect the building vulnerability, and the not yet detailed outline assessment on structural parameters (vertical irregularity and plan irregularity).

In level 2, the assessment on irregularity parameter that caused structure vulnerability was described in more detail, and guided by principles of seismic design. The non-structurally vulnerable potential was also described more clearly. The results of the evaluation level 2 were shown in Figure 2. Vulnerability potential of the structure caused by final score level 2 below cutoff score and or caused by other hazards would require structural detail evaluation. If non-structurally potential vulnerability exists, then it is advisable to conduct a non-structural detail evaluation, as shown in Figure 3. 


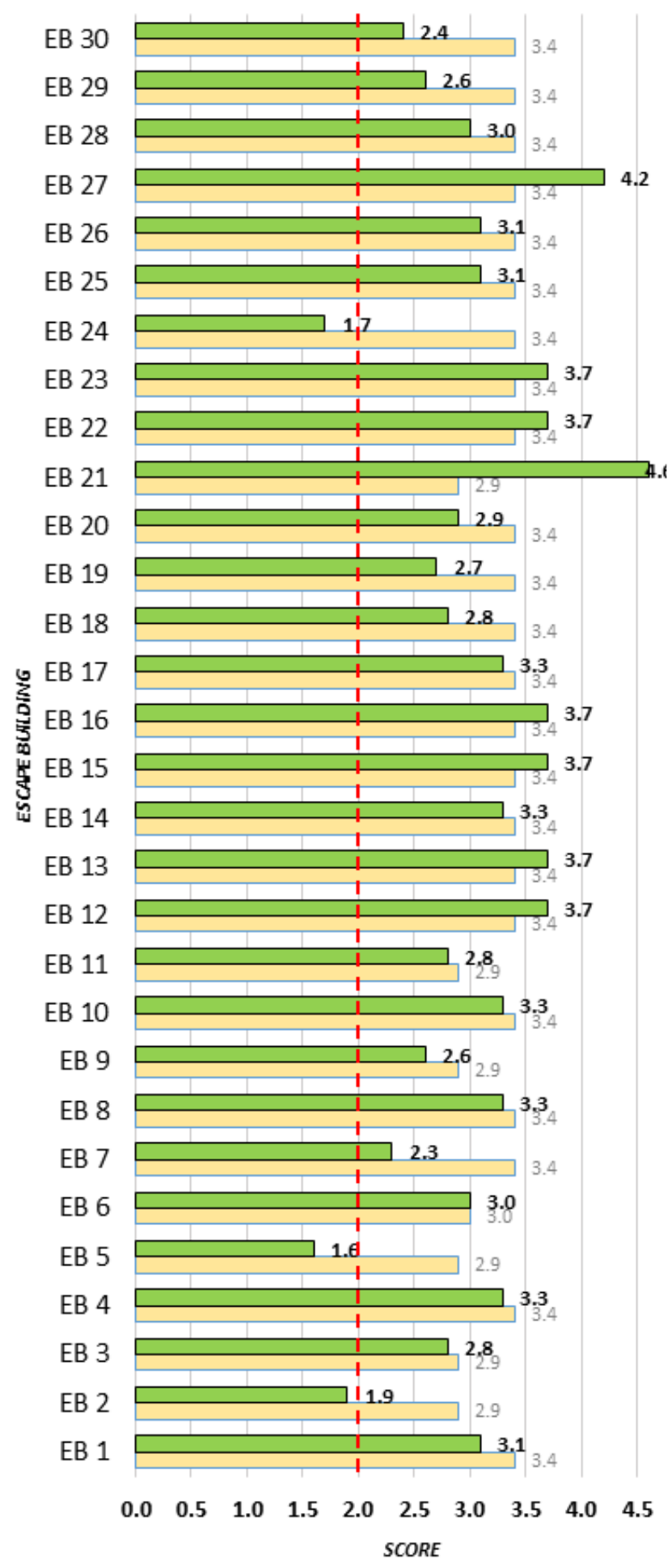

$\square$ Final score level $2 \quad \square$ Adjusted baseline score

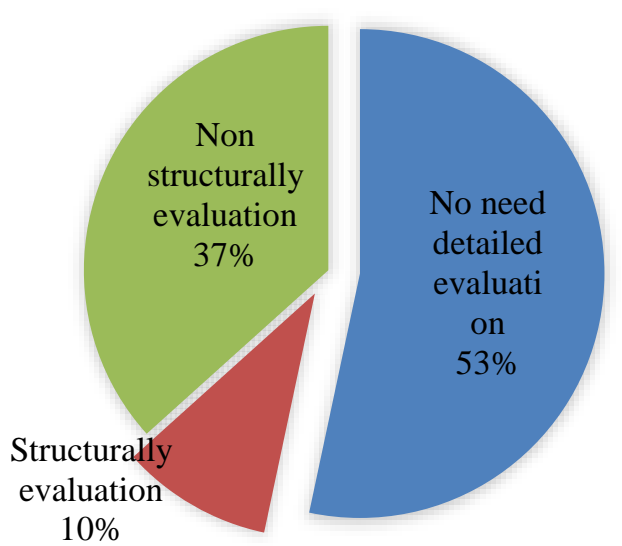

Figure 3. Total of escape building based on recommendation from further details evaluation.

\subsection{Evaluation on Potential Vulnerability of Escape Building to Tsunami with FEMA P-646}

The analysis results of every escape building that has tendency to be safe zone were then further analyzed based on the guidelines in the FEMA P-646. Elevation data of existing building level was obtained in 2 means, i.e. height measurement of each level in the building and based on existing pictures of the building structure. Elevation $\pm 0.00 \mathrm{~m}$ is the ground surface elevation in the building site location, not the elevation of floor surface. The benchmark was taken as the elevation of maximal predicted inundation on the location by the guidance of Tsunami Inundation Map from Franzius Institute (2010), in which 30\% was added from this elevation, and was also with the addition from tidal jump factor of 3 meters. Evaluation results on Figure 4 showed that EB 1 and EB 4 were potentially vulnerable to tsunami, or does not fulfill minimal elevation to tsunami inundation. Evaluation on the capacity of the safe zone area for evacuation was needed to discover how large of the tsunami-affected population which could be served by the escape building that fulfills maximal inundation height elevation in each location (Figure 5). With 508,804 people of total population affected by the tsunami (Central Office of Statistics (BPS) of Padang City, 2015), the total capacity of the evacuees that could be served on the safe escape building is 55,634 people, or only $10.93 \%$ from the affected population.

Figure 2. FEMA P-154 level 2 evaluation result on escape building. 


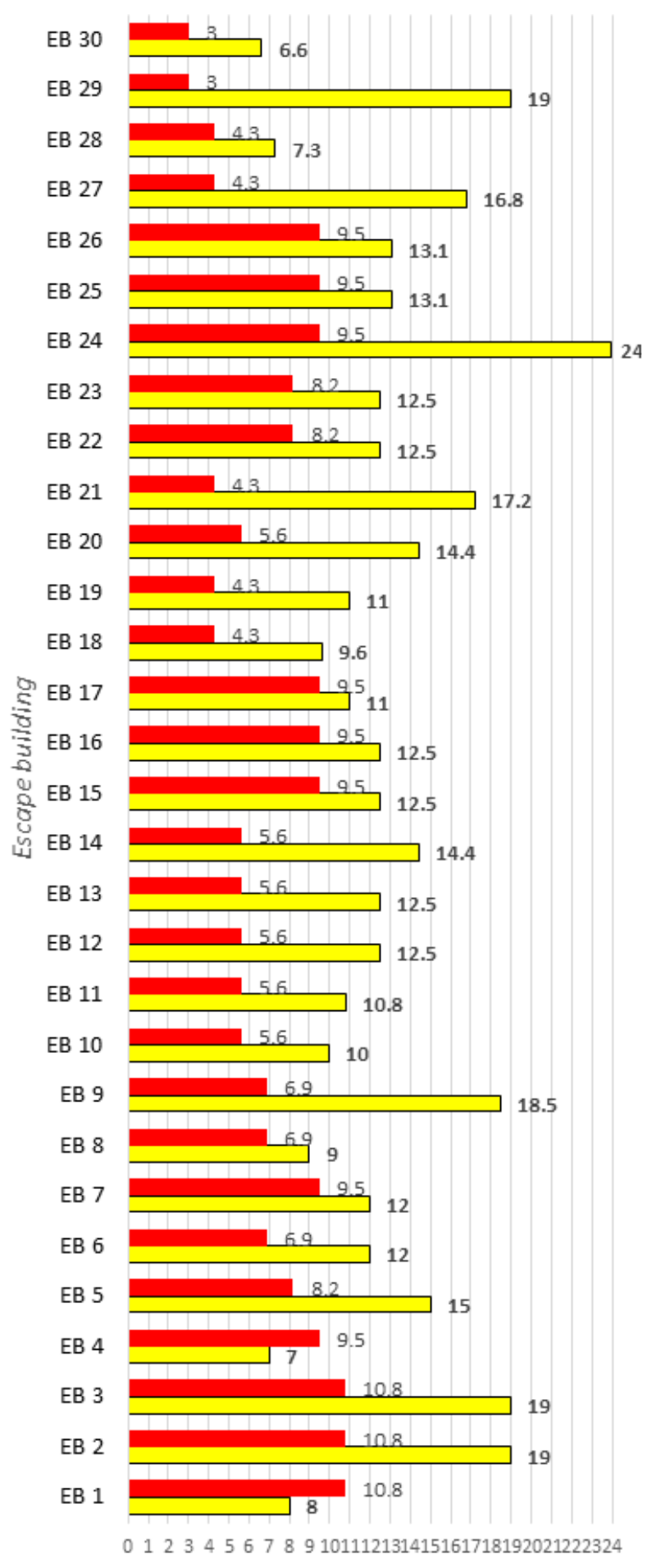

Elevation (m)

Prediction of tsunami $\quad \square \quad$ Building height
inundation

Figure 4. Elevation of escape building to tsunami inundation.

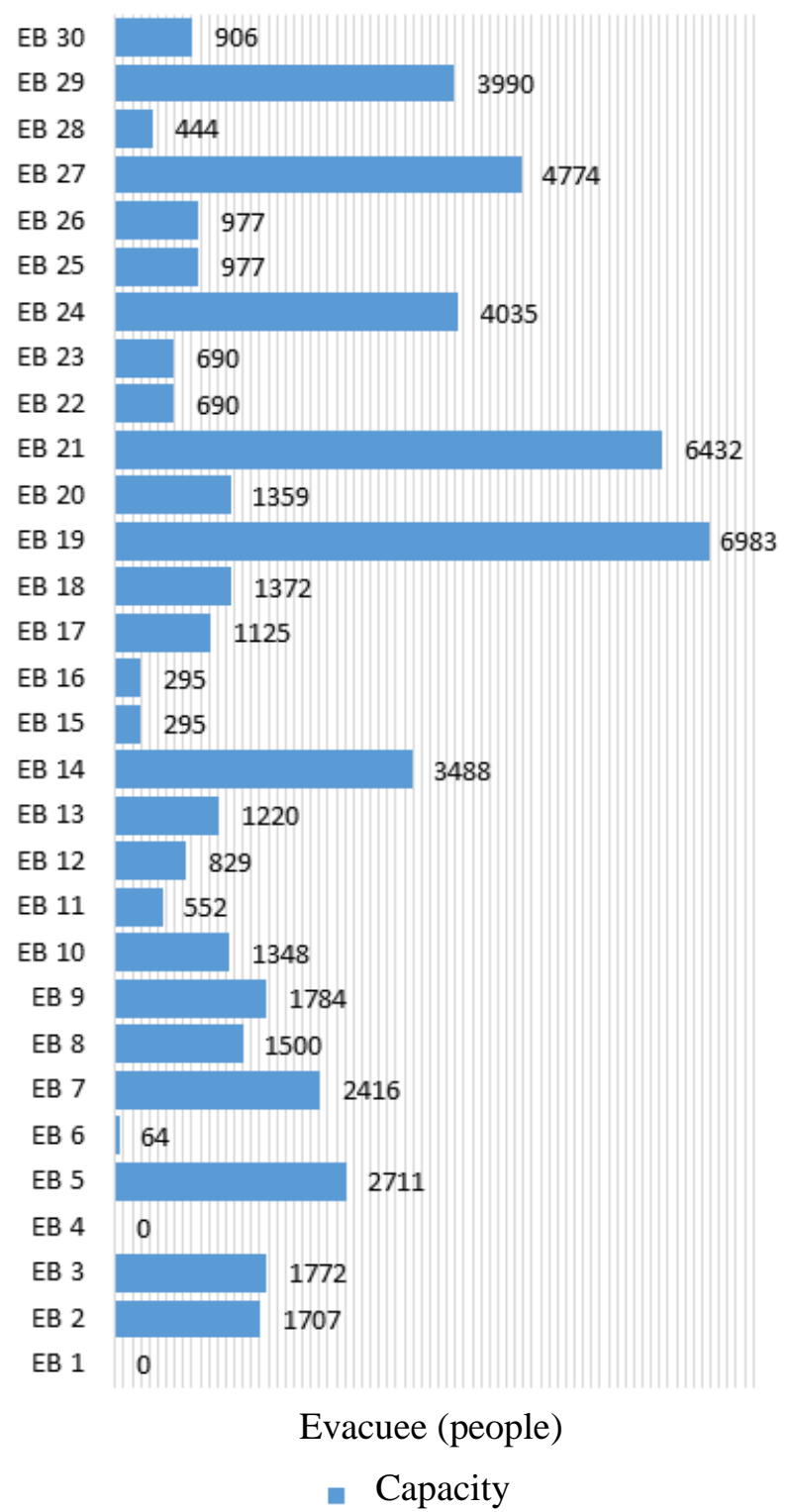

Figure 5. Prediction of maximal capacity of escape building.

The evaluations of site location of escape building consisted of several analyses:

1) Distance to escape building that associated with travel time of tsunami wave to mainland. This study used the worst-case scenario which was tsunami caused by near-source-generated tsunami. The travel time of the first wave of this type of tsunami was less than 30 minutes (FEMA P-646, 2012). Triatmadja (2010) stated that if tsunami was raised by fault area, then it took about 27 minutes to reach the mainland. To calculate the effective evacuation time, in estimation, it would need 7-10 minutes for warning, and the time left for evacuation in 15-20 minutes. Therefore, by using calculation of human speed in community that consist of children, adolescents, adults, and seniors (Triatmadja, 2010), 
and average speed of ambulatory or sick person (FEMA P-646, 2012), reference for evaluation of distance/radius maximal of community to escape building, which is shown in Table 1.

Table 1. Maximum distance of evacuation to escape building (Triatmadja, 2010)

\begin{tabular}{lllll}
\hline $\begin{array}{l}\text { Tsunami } \\
\text { arrival } \\
\text { time } \\
\text { (minute) }\end{array}$ & Category & $\begin{array}{l}\text { Average } \\
\text { velocity } \\
\text { on } \\
\text { asphalt } \\
\text { surface } \\
(\mathrm{m} / \mathrm{s})\end{array}$ & $\begin{array}{l}\text { Evacuation } \\
\text { travel time } \\
\text { (minute) }\end{array}$ & $\begin{array}{l}\text { Max. } \\
\text { mileag } \\
\text { e } \\
(\mathrm{m})\end{array}$ \\
\hline 27 & Children & 2.4 & 15 & 2.16 \\
27 & Adolescent & 4.13 & 15 & 3.717 \\
27 & Adult & 3.3 & 15 & 2.97 \\
27 & Senior & 1.84 & 15 & 1.656 \\
27 & Ambulatory & 0.89 & 15 & 804 \\
\hline
\end{tabular}

2) Hazard zone area is the potential of debris source and dangerous material source attacking the escape building location which could disrupt the evacuation process and endanger the building structure. The investigation of the existing 25 escape building locations showed that the areas are relatively safe.

3) Accessibility, which means that the escape building should have a good and clear access, and can lead or guide the internal or external evacuees during the evacuation at earthquake or tsunami occurs. An effective evacuation route will reduce risks of tsunami and earthquake hazards since the rescue of evacuees on tsunami would need time efficiency. The inner site circulation of the escape building must be able to lead evacuees to gathering point, for which then eventually to the safe zone in the building. The ramp and stairs facilities should be available to accommodate evacuees that are sick or with special needs. Emergency stairs outside the building are also highly needed to reduce the evacuation time. From the evaluation result, the escape buildings that have most complete facilities are EB10, EB2, EB3 and EB9.

\subsection{Result of Assessment on Potential Vulnerability} of Escape Building to Earthquake and Tsunami

Based on the evaluation of potential vulnerability of escape building to earthquake and tsunami, resume that shows parameter of vulnerability on every escape building is arranged as shown in Table 2. Evaluation in Table 2 can be summarized as follows: a) Number of escape buildings relatively safe from earthquake and tsunami were 15 including Nurul Haq Mosque (EB3), TES Villa Hadis (EB6), Regional House of Representative of West Sumatera Province (EB8), TES Ulak Karang (EB9), West Sumatera Audit Board of the Republic of Indonesia (EB11), SMA 1 (EB14), SMKN 5 (EB17), West Sumatera Regional Office of State Treasury Directorate General (EB18), Sumbar Great Mosque (EB19), West Sumatera Province Office of Road Facilities, Spatial Planning, and Settlements (EB21), Rental Flats Building A (EB25) and Building B (EB26), West Sumatera Regional Secretariat (EB27), Bank Indonesia (EB28), and Grand Zuri Hotel (EB29)

b) Number of escape buildings that were structurally safe ( $S L \geq 2)$, but vulnerable to non-structural damaged were 10 including Library of Bung Hatta University (EB7), SD Islam Al-Azhar (EB10), SMP 25 Building A (EB12) and Building B (EB13), SMP 7 Building A (EB15) and Building B (EB16), West Sumatera Province of Regional Development Planning Board (EB20), SD 23 (EB22), SD 24 (EB23) and Nurul Iman Mosque (EB30)

c) Number of escape buildings that were structurally vulnerable to structural hazards determined by Level 2 final score below the cut-off score (SL2<2) were 3 including Darussalam Mosque (EB2), Faculty of Art \& Language of Padang State University (EB5), and Mercure Hotel (EB24)

d) Escape buildings that were vulnerable to tsunami inundation determined by the elevation which did not fulfill the tsunami inundation were 2 including Al-Muhajirin Mosque (EB1). and Faculty of Sports Science of Padang State University (EB4);

e) Evaluation of vulnerability against tsunami and earthquake resulted in 4 categories of vulnerability, as shown in Figure 6.

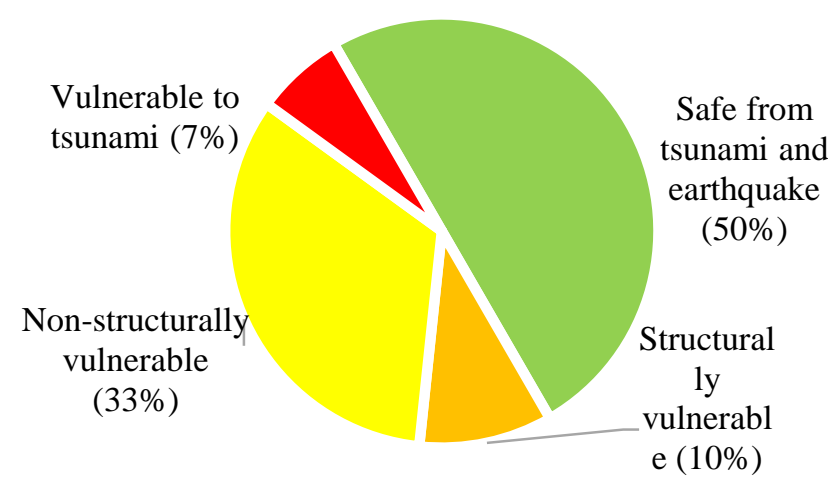

Figure 6. Evaluation result on potential vulnerability of escape building to earthquake and tsunami. 
Table 2. Result of assessment on potential vulnerability of escape building to earthquake and tsunami

\begin{tabular}{|c|c|c|c|c|c|c|c|c|}
\hline \multirow[b]{3}{*}{ Escape building } & & & \multicolumn{5}{|c|}{ Vulnerability parameter } & \multirow[b]{3}{*}{$\begin{array}{l}\text { Potential vulnerability } \\
\text { evaluation from earthquake } \\
\text { and tsunami }\end{array}$} \\
\hline & & & \multicolumn{3}{|c|}{ FEMA P-154 } & \multicolumn{2}{|c|}{ FEMA P-646 } & \\
\hline & & & 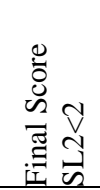 & 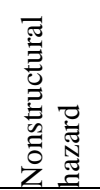 & 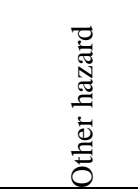 & 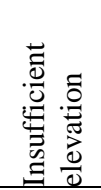 & 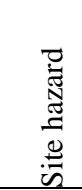 & \\
\hline Al Muhajirin Mosque & $:$ & EB 1 & - & - & & $v$ & - & Tsunami inundation \\
\hline Darussalam Mosque & $:$ & EB 2 & $v$ & $v$ & landslide & - & - & Structurally vulnerable \\
\hline Nurul Ha'q Mosque & $:$ & EB 3 & - & - & & - & - & Safe \\
\hline Faculty of Sport Science, Padang State Univ. & $:$ & EB 4 & - & $v$ & & $v$ & - & Tsunami inundation \\
\hline Faculty of Art \& Language, Padang State Univ. & : & EB 5 & $v$ & - & & - & - & Structurally vulnerable \\
\hline TES Villa Hadis & : & EB 6 & - & - & & - & - & Safe \\
\hline Library of Bung Hatta Univ. & : & EB 7 & - & $v$ & & - & - & Non-structurally vulnerable \\
\hline DPRD Sumbar (Regional House of Representative of West Sumatera Province) & : & EB 8 & - & - & & - & - & Safe \\
\hline TES Ulak Karang & : & EB 9 & - & - & & - & - & Safe \\
\hline SD Islam Al-Azhar & : & EB 10 & - & $v$ & & - & - & Non-structurally vulnerable \\
\hline BPKRI Sumatera Barat (West Sumatera Audit Board of the Republic of Indonesia) & : & EB 11 & - & - & & - & - & Safe \\
\hline SMP 25 Building A & : & EB 12 & - & $v$ & & - & - & Non-structurally vulnerable \\
\hline SMP 25 Building B & : & EB 13 & - & $v$ & & - & - & Non-structurally vulnerable \\
\hline SMA 1 Padang & : & EB 14 & - & - & & - & - & Safe \\
\hline SMP 7 Building A & : & EB 15 & - & $v$ & & - & - & Non-structurally vulnerable \\
\hline SMP 7 Building B & $:$ & EB 16 & - & $v$ & & - & - & Non-structurally vulnerable \\
\hline SMKN 5 Padang & : & EB 17 & - & - & & - & - & Safe \\
\hline Kanwil DJPN (Regional Office of State Treasury Directorate General) & : & EB 18 & - & - & & - & - & Safe \\
\hline West Sumatera Great Mosque & : & EB 19 & - & - & & - & - & Safe \\
\hline Bappeda (Regional Development Planning Board) & : & EB 20 & - & $v$ & & - & - & Non-structurally vulnerable \\
\hline Dinas PJTRP (Office of Road Facilities, Spatial Planning, and Settlements) & : & EB 21 & - & - & & - & - & Safe \\
\hline SDN 23 & : & EB 22 & - & $v$ & & - & - & Non-structurally vulnerable \\
\hline SDN 24 & $:$ & EB 23 & - & $v$ & & - & - & Non-structurally vulnerable \\
\hline Mercure Hotel & : & EB 24 & $v$ & - & & - & - & Structurally vulnerable \\
\hline Rental Flats Building A & : & EB 25 & - & - & & - & - & Safe \\
\hline Rental Flats Building B & $:$ & EB 26 & - & - & & - & - & Safe \\
\hline Sekda (Regional Secretariat) & : & EB 27 & - & - & & - & - & Safe \\
\hline Bank Indonesia & $:$ & EB 28 & - & - & & - & - & Safe \\
\hline Grand Zuri Hotel & : & EB 29 & - & - & & - & - & Safe \\
\hline Nurul Iman Mosque & : & EB 30 & - & $v$ & & - & - & Non-structurally vulnerable \\
\hline
\end{tabular}




\section{CONCLUSIONS AND RECOMMENDATIONS}

\subsection{Conclusions}

From evaluation result on the potential vulnerability of escape building in Padang City to earthquake and tsunami hazards, several conclusions could be made as follows:

a) The location of escape building in Padang City is a high seismicity area $(1 \mathrm{~g} \leq \mathrm{SS}<1.5 \mathrm{~g}$ and $0.4 \mathrm{~g} \leq$ $\mathrm{S} 1<0.6 \mathrm{~g}$ ).

b) Irregular structure designs of escape buildings in Padang City could cause plan irregularity and vertical irregularity in certain condition, which then would affect structure vulnerability.

c) Non-structural elements such as architecture, furniture, accessories, inter-building condition, geology of location, could increase the vulnerability of escape building in Padang City and also endanger human safety.

d) Based on result of combination evaluation of FEMA P-154 and FEMA P-646, the escape building in Padang City that is identified to be potentially safe from earthquake and tsunami are 15 buildings (50\%), escape buildings that are vulnerable to non-structural hazard are 10 buildings (33\%), escape buildings that are vulnerable to structural hazard are 3 buildings $(10 \%)$, and those which vulnerable to tsunami are 2 buildings ( $7 \%$ ).

\subsection{Recommendation}

The followings are some recommendation that can be fruitful for the latter research:

a) The need for data on complete construction documents, such as as-built drawing, data on SPT/Cone Penetration Test, technical specification and execution photographs, in order to obtained a more accurate research result because several of multi-functioned escape building in Padang City have limited area and could not be accessed publicly, therefore making it difficult to conduct a thorough observation.

b) The need for periodical socialization from the government through the Regional Disaster Management Agency of West Sumatera Province and Regional Disaster Management Agency of Padang City to the owners, managers, and users of the buildings that are about to be used as escape building; this is due to the high frequency of rotation and mutation, which makes it difficult in the process of data request and research survey.

c) The need for special study to complete the evaluation on potential vulnerability of non- structural hazard to earthquake by using FEMA 74FM, which discusses special non-structural elements, such as architecture, utility, and building furniture.

d) Based on the highest SL2 value from evaluation of potential vulnerability to earthquake, the escape building of Office of Road Facilities, Spatial Planning, and Settlements could be a reference for structurally and non-structurally safe design.

e) The non-physical mitigation effort that could be implemented is drilling or rescue simulation to the population that is exposed to earthquake and tsunami in Padang City, about circulation to escape building and to safe zone inside the escape building.

f) Physical efforts that could be made by the government is increasing the number of escape building equally on location of the underserved threatened population, and immediately realizing other tsunami mitigation programs, such as construction of elevation road that is planned along the coast (tsunami-prone zone), and evacuation park, therefore it is expected to be able to accommodate all the residents that are exposed to tsunami.

\section{REFERENCES}

BNPB, 2007. UU RI No 27 Tahun 2007 Tentang Penanggulangan Bencana Alam [Natural Disaster Mitigation], Jakarta: BNPB (National Disaster Management Office).

BPBD Padang, 2016. Rencana Kontinjensi Menghadapi Bencana Tsunami Provinsi Sumatera Barat [Mitigation Plan towards tsunami Hazard in West Sumatera Province], Padang: BPBD (Regional Disaster Management Office) .

Central Office of Statistics (BPS) of Padang City, 2015. Padang dalam Angka/Padang in Figures, Padang: BPS.

FEMA P-154, 2015. Rapid Visual screening of Buildings for Potential Seismic Hazards. A Handbook Third Edition ed. Washington, DC: FEMA.

FEMA P-646, 2012. Guidelines for Design of Structures for Vertical Evacuation from Tsunamics. 2nd Edition ed. Washington, DC: FEMA.

Franzius Institute, 2010. Pemetaan Bahaya dan Inundasi [Hazard Risk and Inundation Mapping], Padang: Last-Mile Evacuation Project.

Hunt, R. E., 2007. Geologic Hazards A Field Guide for Geotechnical Engineers. New York: MCGraw-Hill. 
Triatmadja, R., 2010. Tsunami Kejadian, Penjalaran, Daya Rusak dan Mitigasinya [Occurrence, Streamline Flow, Destructive Force, and Mitigation]. Yogyakarta: UGM Press.

Zulfiar, M. H., Tamin, R. Z., Pribadi, K. S. \& Imran, I., 2014. Identifikasi Faktor Dominan Penyebab
Kerentanan Bangunan di Daerah Rawan Gempa Provinsi Sumatera Barat. Jurnal Ilmiah Semesta Teknika, 7(2), pp. 116-125. 
[this page is intentionally left blank] 